\title{
A Research on Production Potential and Development Opportunities of Pistachio (Pistacia vera L.) in Turkey
}

\author{
Mikdat Şimşek ${ }^{1}$, and Ersin Gülsoy ${ }^{2}$ \\ ${ }^{1}$ Department of Horticulture, Faculty of Agriculture, Dicle University, Diyarbakir, CO 21280, Turkey \\ (corresponding author's phone: +90 412 2411000; e-mail: mikdat.simsek@dicle.edu.tr). \\ ${ }^{2}$ Department of Horticulture, Faculty of Agriculture, İgdir University, İgdir, CO 76000, Turkey \\ (E-mail: ersin.gulsoy@igdir.edu.tr).
}

\begin{abstract}
Pistachio is one of the oldest cultivated agricultural products called as 'Green Gold' in Turkey. Anatolia is the gene centre of Pistachio. The richness of our country on genetic variation of this species provides facility for achievement in breeding studies in a short period of time. Because this fruit is cultivated on some regions of Anatolia, it is extremely important to develop cultivars proper for some regions. The world has 1.023.000 tons of total pistachio production. According to 2015 statistics Turkey has 144.000 tons of total pistachio production. Considering the total pistachio production by the regions in Turkey, Southeast Anatolia and Aegean regions rank first and second with 134.481 and 4.197 tons of pistachio productions respectively as West Blacksea Region is the last with a production of 73 tons. Considering the total pistachio production of the provinces in the our country, Gaziantep and Şanliurfa provinces rank first and second with 53.109 and 47.848 tons of pistachio productions respectively as Erzincan and Afyon provinces come last with a production of only 1 ton. In this study, through presenting the existing status of the pistachio production of Turkey, it was aimed to increase the awareness and set light to decision makers for making use of and directing the existing potential in future plans.
\end{abstract}

Keywords: Development opportunity, Pistachio, Production potential, Turkey.

\section{Introduction}

Pistachio nut (Pistacia vera L.) is one of the most popular tree nuts in the World [1]. This nut tree belongs to the family Anacardiaceae and dioecious and deciduous native species [2]. This fruit is the richest source of hearthealthy fatty-acids, metals, phytosterols, phenolic and other compounds and therefore their consumption has become increasingly popular over the past decade [3].

Pistachios are served principally as salted nuts. A large percentage of pistachios are marketed in the shell for snack food. The food industry uses pistachios for cakes, biscuits, pies, candies, ice cream and pistachio butter. It is also used as the main ingredient of many Turkish desserts. This nut contains $25 \%$ protein (mainly essential amino acids), 16\% carbohydrate (mainly sucrose) and 55\% oil (80\% unsaturated fatty acids) [4]-[5].

Turkey has a large potential of fruit species and fruit production [6], [7]. Anatolia is one of the important pistachio-producing countries, with $14.08 \%$ of the world. The world has about 1.023 .000 tons of total pistachio production. The largest producer of pistachio in the world is Iran with 480.000 tons. After Iran, USA, Turkey, China and Syria produce 240.000, 144.000, 80.000 and 57.000 tons annually, respectively [8].

It is a gene centre for many fruit species such as pistachio, apricots, figs, hazelnuts, almonds, walnuts, pomegranates, apple and cherry. According to archaeological research, It has been known that many fruit species were grown in Anatolia a few thousand years ago [9]-[13]. 
Pistachio's wild trees are spread in almost all parts of Anatolia. However, the majority of this species's trees are in the South Eastern part of the country. Because the climate of this region is quite suitable for growth of Pistacia trees or shrubs. Eventually this region is the most important area for pistachio nut production although the annual precipitation is very low $(300-500 \mathrm{~mm})$, the soils are poor, stony, calcareous and summers are very hot and dry and the winters are rather cold. So in a way pistachio nut is grown in Turkey in marginal lands where no other fruit or even field crops can be grown economically unless some cultural measures such as irrigation, fertilization are taken.

In this study, through presenting the existing status of the pistachio production of Turkey, it was aimed to increase the awareness and set light to decision makers.

\section{Some Important Pistachio Cultivars in Turkey}

Turkey has about twenty pistachio cultivars. Pistachio cultivars such as Siirt, Halebi, Ohadi, Uzun, Kirmızı, Keten Gömleği, $\square$ Beyaz Ben, Değirmi, Çakmak, Sultani, Vahidi, Mümtaz, Sefidi and Hacı Şerifare grown in Turkey. However, But, the most popular pistachio cultivars in our country are Siirt, Kirmizi and Uzun [14].

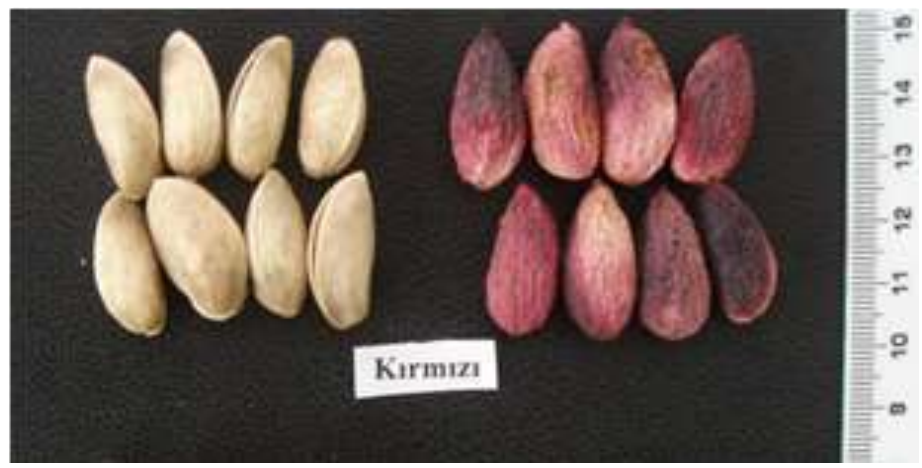

Fig. 1: Kirmız1 Cultivar [15].

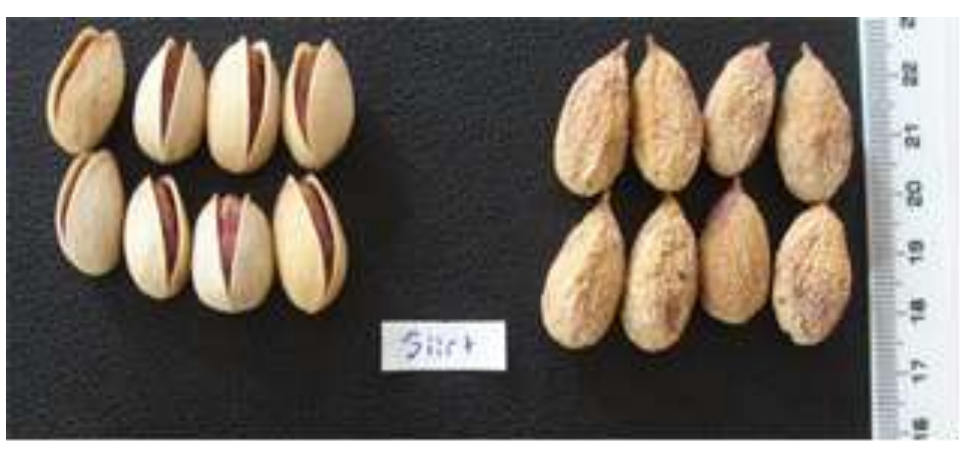

Fig. 2: Siirt Cultivar [16].

\section{Turkey's Pistachio Production}

Turkey has 144.000 tons of total pistachio production [17]. Considering the total pistachio production by the Regions in Turkey, Southeast Anatolia and Aegean regions rank first and second with 134.481 and 4.197 tons of pistachio productions respectively as West Blacksea Region is the last with a production of 73 tons. Pistachio production is carried out in 40 provinces in Turkey. Considering the total pistachio production of the provinces in the our country, Gaziantep and Şanliurfa provinces rank first and second with 53.109 and 47.848 tons of pistachio productions respectively as Erzincan and Afyon provinces come last with a production of only 1 ton (Table 1). 
TABLE I: Pistachio Trees's Numbers and Production of Turkey's Provinces.

\begin{tabular}{|c|c|c|c|c|c|c|}
\hline Provinces & $\begin{array}{l}\text { Area covered by } \\
\text { bulk fruit (decare) }\end{array}$ & $\begin{array}{l}\text { Production } \\
\text { (tons) }\end{array}$ & $\begin{array}{l}\text { Average yield per } \\
\text { tree (kilogram) }\end{array}$ & $\begin{array}{l}\text { Number of } \\
\text { fruitful trees }\end{array}$ & $\begin{array}{l}\text { Number of } \\
\text { unfruitful trees }\end{array}$ & Total number of trees \\
\hline Erzincan & 10 & 1 & 3 & 360 & 12 & 372 \\
\hline Malatya & 569 & 198 & 6 & 30.770 & 955 & 31.725 \\
\hline Elazı ̆̆ & 20 & 78 & 7 & 10.610 & 2.140 & 12.750 \\
\hline Tunceli & 121 & 20 & 6 & 3.200 & 1.090 & 4.290 \\
\hline Bitlis & 76 & 26 & 4 & 5.850 & 4.650 & 10.500 \\
\hline Hakkari & 80 & 29 & 7 & 4.200 & 350 & 4.550 \\
\hline Gaziantep & 1.299 .203 & 53.109 & 3 & 16.412 .510 & 3.575 .368 & 19.987 .878 \\
\hline Adiyaman & 254.397 & 15.368 & 4 & 4.209 .355 & 862.476 & 5.071 .831 \\
\hline Kilis & 59.477 & 2.271 & 3 & 713.724 & 237.908 & 951.632 \\
\hline Şanlıurfa & 968.629 & 47.848 & 4 & 12.843 .690 & 4.348 .102 & 17.191 .792 \\
\hline Diyarbakır & 4.384 & 1.408 & 10 & 139.980 & 78.005 & 217.985 \\
\hline Mardin & 10.021 & 1.659 & 9 & 178.157 & 138.516 & 316.673 \\
\hline Batman & 20.670 & 1.654 & 5 & 340.335 & 255.802 & 596.137 \\
\hline Şırnak & 2.493 & 43 & 4 & 10.160 & 61.777 & 71.937 \\
\hline Siirt & 190.663 & 11.221 & 4 & 2.742 .800 & 1.219 .000 & 3.961 .800 \\
\hline Balıkesir & 67 & 101 & 3 & 31.040 & 25.895 & 56.935 \\
\hline Çanakkale & 4.711 & 691 & 2 & 377.076 & 14.060 & 391.136 \\
\hline İzmir & 6.680 & 1.179 & 5 & 242.935 & 58.817 & 301.752 \\
\hline Aydın & 3.924 & 384 & 2 & 164.140 & 44.395 & 208.535 \\
\hline Denizli & 348 & 403 & 3 & 145.670 & 3.475 & 149.145 \\
\hline Muğla & 1.515 & 172 & 2 & 82.095 & 10.500 & 92.595 \\
\hline Manisa & 10.500 & 1.825 & 3 & 615.956 & 253.767 & 869.723 \\
\hline Afyon & 38 & 1 & 1 & 862 & 0 & 862 \\
\hline Kütahya & 2.171 & 149 & 3 & 47.925 & 51.080 & 99.005 \\
\hline Uşak & 147 & 79 & 4 & 18.565 & 5.630 & 24.195 \\
\hline Bursa & 0 & 14 & 4 & 4.000 & 200 & 4.200 \\
\hline Eskişehir & 51 & 13 & 5 & 2.715 & 390 & 3.105 \\
\hline Ankara & 0 & 15 & 1 & 15.500 & 13.000 & 28.500 \\
\hline Konya & 100 & 44 & 3 & 14.023 & 10 & 14.033 \\
\hline Karaman & 950 & 324 & 4 & 90.000 & 2.000 & 92.000 \\
\hline Antalya & 82 & 18 & 10 & 1.800 & 900 & 2.700 \\
\hline Isparta & 40 & 5 & 2 & 2.800 & 0 & 2.800 \\
\hline Burdur & 33 & 6 & 1 & 7.250 & 1.400 & 8.650 \\
\hline Mersin & 5.224 & 1.156 & 4 & 261.784 & 80.783 & 342.567 \\
\hline Hatay & 0 & 9 & 4 & 2.500 & 100 & 2.600 \\
\hline Kahramanmaraş & 66.603 & 2.197 & 3 & 798.000 & 237.150 & 1.035 .150 \\
\hline Nevşehir & 10 & 4 & 14 & 290 & 400 & 690 \\
\hline Sivas & 56 & 205 & 18 & 11.400 & 42.000 & 53.400 \\
\hline Karabük & 90 & 21 & 12 & 1.800 & 0 & 1.800 \\
\hline Çorum & 26 & 52 & 4 & 11.600 & 870 & 12.470 \\
\hline TURKEY & 2.914 .179 & 144.000 & & 40.597 .427 & 11632973 & 52.230 .400 \\
\hline
\end{tabular}

\section{Development Opportunities of Pistachio in Turkey}

Pistachio producers need to develop policies to get the expected profit from shell nuts together with production plans for domestic consumption and exports. The production producers need to make regular cultural processes to reduce profit inefficiency. Authorized institutions need to reform nut subsidy purchases and subsidy pricing policies. Pistachio yield and quality will increase in case of more contribution to scientific research and will made a positive contribution to the economy both the nut producers and the country. The species's fruits are in the group of risky products in terms of Alfatoxin. Therefore, The nut's storage conditions should be 
emphasized. It is necessary to speed up the breeding works to develop new pistachio varieties to be suitable for different ecological conditions and breeding systems. Necessary measures should be taken and timely and regularly done to prevent diseases and harmfuls. Technical and scientific studies must be done to reduce input cost. The nut's producers have to make agricultural insurance for the loss of natural disasters.

\section{Conclusion}

Pistachio grows in 40 provinces of Turkey. Therefore, pistachio production potential is very important for our country. This nut producers should act in cooperation with other institutions and organizations, for example, agricultural faculties, and other colleges and the universities's institutes and Ministry of Food, Agriculture and Livestock.

\section{References}

[1] L. Aldars-García , A.J. Ramos, V. Sanchis, and S. Marín, "Modelling the probability of growth and aflatoxin B1 production of Aspergillus flavus under changing temperature conditions in pistachio nuts," Procedia Food Science, vol. 7, pp. $76-79,2016$.

[2] G. Bartzas, and K. Komnitsas, "Life cycle analysis of pistachio production in Greece," Science of the Total Environment, vol. 595, pp. 13-24, 2017

[3] M.L. Dreher, "Pistachio nuts: composition and potential health benefits," Nutrition Review, vol. 70, pp. 234-240, 2012.

[4] E.H. Shokraii, and A. Esen, "Composition, solubility and electro-phoretic patterns of protein isolated from kerman pistachio nuts (Pistacia vera L.)," Journal of Agriculture and Food Chemistry, vol.36, pp. 425-429, 1988.

[5] T. Aktas, R. Polat, "Changes in the drying characteristics and water activity values of selected pistachio cultivars during hot air drying," Journal of Food Process Engineering, vol. 30, pp. 607-624, 2007.

[6] M. Simsek, and A. Kara, "Diyarbakir fruit growing potential an overview," International Diyarbakir Semposium, 25 October 2016, Diyarbakır-Turkey (in press).

[7] M. Şimşek, E. Gülsoy, "A Research on pomegranate (Punica granatum L.) production Potential of Southeastern Anatolia Region,” Iğdır University Journal Institute Science \& Technology, vol. 7, pp. 131-141, 2017.

[8] FAO, "Food and Agriculture Organization (FAO)," http://www.fao.org/faostat/en/\#data/QC (Accessed: 10.10.2017), 2015.

[9] S.Z. Bostan, and A. Islam, "Determination of interrelationships among important nut quality characteristics on Palaz and Sivri Hazelnut cultivars by Path Analysis," Turkish Journal of Agriculture and Forestry, vol. 23, pp. 371-375, 1999.

[10] R. Gercekcioglu, and S. Bilgener, and A. Soylu, "General orcharding (Principles of Fruit Growing)," NOBEL Academic Publishing, Improved 4th Edition, Istanbul, 498 p. 2014.

[11] E. Gülsoy, T. Kaya, M. Şimşek, and M. Pehluvan, ”Selections of walnut (Juglans regia L.) in Igdir district," Iğdır University Journal Institute Science \& Technology, vol. 6, pp. 25-30, 2016.

[12] M. Şimşek, "A research on almond growing in Turkey and the state of selection studies," DUFED, vol. 4, 95-100, 2015.

[13] M. Şimşek, "A research on walnut (Juglans regia L.) production in Turkey and the state of selection studies," DUFE, vol. 5, pp. 19-25, 2016.

[14] TREM, "Turkey Republic's Economy Ministry (TREM)," Pistachio. file:///C:/Users/ziraaat/Downloads/antep_fistigisektor-raporu-293.pdf (Accessed: 10.10.2017), 2013.

[15] Anonymous, https://www.google.com.tr/ search?safe $=$ active \&biw $=1366 \& b i h=637 \& t b m=i s c h \& s a=1 \&$ ei $=1 \mathrm{y}$ DyWdP1AuTE6A SZ3obYAg \&q= Antep+F\%C4\%B1 st\%C4\%B1\%C4\%9F\% C4\%B1+Uzun+ \%C3\%87e C5\% 9Fidi +resimleri \&oq =Antep+ F\%C4 \%B1s t\%C4\% B1\% C4\%9F\% C4\%B1+Uzun+\%C3\%87e \%C5\%9 Fidi+ 
resimleri\&gs_l= psy-ab.3...8326.12 838.0.13195.10.10.0.0.0.0.122.1112.0j10.10.0.......1.1.64.psy-ab..0.0.00.LY HtzV Su81g\# imgr c= Fa D 215 yO9 oqIcM: (Accessed: 10.10.2017), 2017a.

"https://

www.google.com.tr/

search?safe $=$ active $\&$ biw $=$ 1366\&bih=637\&tbm=isch\&sa=1\&ei=1 yDyWdP1AuTE6ASZ3obYAg\&q=Antep+F\%C4\%B1st\%C4\%B1\%C4\%9F\% $\mathrm{C} 4 \% \mathrm{~B} 1+\mathrm{Uzun}+\% \mathrm{C} 3 \% 87 \mathrm{e} \% \mathrm{C} 5 \% 9 \mathrm{Fidi}+$ resimleri\&oq=Antep+F\%C4\%B1st\%C4\%B1\%C4\%9F\%C4\%B1+Uzun+\%C3 $\% 87 \mathrm{e} \% \mathrm{C} 5 \% 9$ Fidi+resimleri\&gs_l=psy-ab.3...8326.12838. 0.13 195. 10.10.0.0.0.0.122.1112.0j10.10.0..0...1.1.64.psyab..0.0.0...0.LY HtzVSu81 g\#imgrc=dx0DuaQ7450yAM:(Accessed: 10.10.2017),”2017b.

[17] TSI, ”Turkish Statistical Institute (TSI),”. http://www.turkstat.gov.tr/ Start.do (Accessed:10.10.2017), 2015. 